\title{
ANNUAL REPORT FOR THE YEAR ENDING 31st DECEMBER, 1961
}

\section{Presented by the Council to the Annual General Meeting, 25th April, 1962}

Meetings of the Society.-The Annual General Meeting and two other General Meetings were held. Council met four times.

International Meetings.-The Secretary represented the Society at the VIIth Conference of the European Continental Section of the International Council for Bird Preservation, held in Stavanger, Norway, during June.

Survival Service Commission, IUCN.-The work of the Commission continued to be integrated with that of the Society.

On 23rd June a meeting of the Commission was held at Stavanger by kind permission of the European Section of ICBP. Suggested changes to the List of Endangered Species were considered and implementation of the Commission's Resolution (published in Oryx, V, 6, page 376) on controlling export and import of rare species was discussed.

The support of the Zoological Society of London was obtained for a Private Member's Bill in Great Britain restricting the importation of rare animals in accordance with the export laws of the country of origin. The Commission has expressed its gratitude to Mrs. Diana Spearman and Mr. David James, M.P., members of Council, for their help in this matter, which is being considered, with respect to Great Britain, by the Ministry of Science in co-operation with the Nature Conservancy and other interested bodies.

Lectures.-Many talks on the Society's work, illustrated by slides or films, were given.

Kindred Organizations.-During the year the Society kept in close contact with kindred societies throughout the world.

Membership.-During 1961 the Society's membership rose by 234 to 2,146 Members. The rise may be attributed to organized publicity, to increased interest in the preservation of wild life, and to public appreciation of the present critical situation.

Accounts.-Members will note that there was an excess of expenditure over income of $£ 1,441$ in the General Purposes Account, a reduction in the General Reserve of $£ 2,734$, but an increase of $£ 795$ in the Life Membership Fund.

They will also note, in the Balance Sheet, that at the end of 1961 the Balance of Assets over Liabilities was $£ 15,351$, compared with $£ 17,959$ at the end of 1960 . The reduction can be attributed mainly to expenditure on the African Special Project and a donation to the Kenya Water for Wild Animals Fund.

The African Special Project.-The Society contributed both in money and in effort towards the success of Stages I and II of ASP. Reports of these Stages and of the plans for Stage III were given in Oryx.

Publications.-The usual three issues of Oryx were published, volume VI, No. 3, being devoted to Africa and printed in September, instead of November, so that 200 copies could be sent to the Arusha Conference. 
Ten thousand copies of the illustrated booklet " Huxley in Africa" were distributed with the co-operation of The Observer, the Colonial Office, and the Commonwealth Relations Office.

Publicity.-The Council wishes to express its appreciation of the work of its Public Relations Officer, Mr. John Hillaby.

Films.-The Society's films, a list of which is given in each issue of Oryx, were much used, especially during the winter months. Some of these films have reached the end of their useful life and have been replaced.

World Wildlife Fund.-The Society collaborated with the Fund from its inception on 28th September. The Marquess of Willingdon, President of the Society, was appointed a Trustee of the British National Appeal. Acknowledgments. - Thanks are offered to those who gave lectures and showed films on behalf of the Society.

The Society is most grateful to the Zoological Society of London for office accommodation and for the unstinted help given by that Society's staff throughout the year. 